\title{
Characteristics of current challenges, risks and uncertainties in the field of natural resource management
}

\author{
N.V. Grevtsev, T.A. Lebedeva, V.V .Belov, and N.S. Ivanova \\ Ural State Mining University, 620144, 30, Kuibyshev St., Ekaterinburg, Russia
}

\begin{abstract}
Modern challenges, environmental risks and economic uncertainties in the field of natural resource management in the Urals and Western Siberia are considered. Information relating to the regional changes in the soil surface (air) temperature, the state of the cryolitic zone of the forest and swamp ecosystems, and extreme uncertainties is presented.
\end{abstract}

\section{Introduction}

The tough environmental (pollution and transformation of the environment), economic (consequences of crises, fluctuations in the product markets), social (high levels of the population stratification, increased protest activity of civil society) and technological (reduction of available resources, deterioration of its quality) situation in various areas of natural resource management require a deep analysis of relations between the environmental, economic, social and technological factors of industrial regions. At present, the raw material base of the mining industry consists of the poor, complex, geodynamically dangerous zones, finely disseminated ores $[1,2,3]$. In the forest industry of the Russian Federation, the lack of modern chemical-mechanical and chemical wood processing does not allow to follow the trend of increasing the cost of marketable products in the case of stability of the timber harvesting facilities. Thus, in the world the plywood production has increased by 1.58 times, the chipboard production - by 2.37 times, the fiberboard production -by 3.61 times, the paper and cardboard production - by 1.59 times [4, p. 75].

Under the modern conditions in the field of subsurface management, it is no longer possible to maintain a favorable environment only by increasing the financial resources for environmental protection measures. In the economic and technological sectors of subsurface management, it is no longer sufficient to maintain and develop the raw material base only by increasing the volume of geologic exploration activities, it is no longer effective to establish new mining and technological industries only by increasing the labor and material technical resources. In the social sector of subsurface management, the formation of a relaxed social environment is no longer possible only due to the traditional employment methods in the field of subsurface management, regulation of labor remuneration, and fiscal operations. New approaches and methods are required [5]. 


\section{Environmental risks}

Environmental risks in the Urals and Western Siberia in the forest land sector consist of an increase in the average soil surface temperature, changes in the state of criolitic zones and forest and swamp areas, an increasing frequency of extreme weather conditions and an increase in their values.

An increase in the air-ground interface average temperature, global warming on Earth was officially recognized as a scientific fact at the UN Intergovernmental Madrid Conference in 1995. The fluctuations in air temperature with different time period (both long-term and short-term) were detected throughout the entire Earth's geological history [6]. Moreover, the branches of long-term periods are complicated by the shorter periods (Fig. 1).

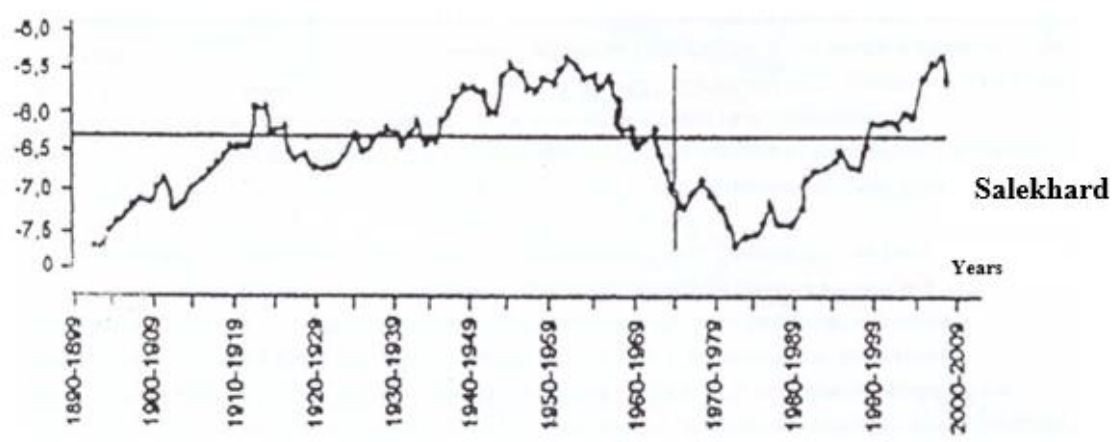

Fig. 1. Long-term variation of air temperature by the weather stations in Western Siberia for the period from the beginning of observations (Shpolyanskaya, 2013, p. 39)

According to the report of the Federal Service of Russia on Hydrometeorology and Monitoring of the Environment (2009-2013), the average annual temperature of the airground interface in Russia is growing much faster than in other parts of the Earth, and the warming intensity has increased significantly over the past decades. The average rate of temperature increase in $1976-2006$ in Russia amounted to $0.43^{\circ} \mathrm{C}$ per decade (for the same period, such value for the entire Northern hemisphere was $0.32^{\circ} \mathrm{C}$, for the entire Earth $0.16^{\circ} \mathrm{C}$ ), while for the previous period it was $0.13^{\circ} \mathrm{C}$ per decade. Over the past decades, the average annual temperature in the North has been growing much faster than in other places.

Table 1 shows information relating to the changes in air temperature according to three weather stations of the Urals and Western Siberia [7].

Table 1. Changes in the air temperature according to the weather stations "Troitsko-Pecherskoye", "Pechora", "Saranpaul" for the period from 1888 to 2000.

\begin{tabular}{|c|c|c|c|c|c|c|c|c|c|c|c|c|c|}
\hline \multirow{3}{*}{ Station } & $\begin{array}{c}\text { Compared } \\
\text { periods } \\
\text { years }\end{array}$ & \multicolumn{10}{|c|}{ Month } \\
& I & II & III & IV & V & VI & VII & VIII & IX & X & XI & XII \\
\hline Saranpaul & $1961-2000$ & -23.4 & -20.6 & -10.9 & -3.7 & 3.9 & 12.1 & 16.3 & 12.3 & 6.1 & -2.9 & -14.4 & -20.4 \\
\cline { 2 - 12 } & $1888-1920$ & -24.0 & -20.8 & -13.8 & -3.5 & 3.8 & 12.0 & 16.1 & 12.6 & 6.2 & 3.7 & -15.6 & -21.8 \\
\cline { 2 - 12 } & Differences & 0.6 & 0.2 & 2.9 & -0.2 & 0.1 & 0.1 & 0.2 & -0.4 & -0.1 & 0.8 & 1.2 & 1.4
\end{tabular}




\begin{tabular}{|l|c|c|c|c|c|c|c|c|c|c|c|c|c|}
\hline Pechora & $1961-2000$ & -19.9 & -17.0 & -9.1 & -3.3 & 3.5 & 11.7 & 16.0 & 11.9 & 6.3 & -1.6 & -10.6 & -15.9 \\
\cline { 2 - 13 } & $1888-1920$ & -20.3 & -17.6 & -12.3 & -3.3 & 3.2 & H,3 & 15.6 & 12.3 & 6.3 & -2.5 & -12.0 & -18.0 \\
\cline { 2 - 13 } & Differences & 0.5 & 0.6 & 3.2 & 0.0 & 0.2 & 0.4 & -0.4 & -0.4 & 0.0 & 0.8 & 1.4 & 2.2 \\
\hline \multirow{3}{*}{$\begin{array}{l}\text { Troitsko- } \\
\text { Pecherskoye }\end{array}$} & $1961-2000$ & -18.3 & -15.6 & -7.3 & -0.5 & 6.0 & 12.9 & 16.3 & 12.3 & 6.7 & -0.8 & -9.3 & -14.7 \\
\cline { 2 - 12 } & $1888-1920$ & -18.9 & -15.9 & -9.6 & -0.5 & 5.7 & 12.8 & 16.0 & 12.8 & 6.8 & -1.6 & -10.5 & -16.7 \\
\cline { 2 - 11 } & Differences & 0.6 & 0.4 & 2.3 & 0.0 & 0.3 & 0.1 & 0.3 & -0.5 & -0.1 & 0.8 & 1.2 & 2.0 \\
\hline
\end{tabular}

The air temperature for the period from 1888 to 2000 has increased by $0.6-0.8^{\circ} \mathrm{C}$.

According to three weather stations of the Khanty-Mansiisk Autonomous DistrictYugra, for the subsequent period in 2000-2006, the average long-term air temperature is $1.0-1.5^{\circ} \mathrm{C}$ higher than for the period in 1961-1990, i.e. the average temperature growth rate was also about $0.4^{\circ} \mathrm{C}$ per decade.

The more significant increase in temperature is observed during the cold seasons of the year (winter, spring); the warming intensity is increasing west-to-east (from the Urals to Western Siberia).

The duration of modern warming depends on its nature. If it is the result of industrial emissions into the atmosphere, then it is possible to expect the continued directional growth in temperature. If it turns out to be just a branch of natural 30-year temperature fluctuations, then the increase in air temperature may soon be terminated. The detailed researches $[8,9,10,11]$ incline to the leading role of the natural fluctuation processes.

Changes in the state of criolitic zone (continuous permafrost zone) in the northern territories. The significant researches on the state and changes of the continuous permafrost zone in the northern hemispheres of the Earth are carried out abroad: reports of the UN Intergovernmental Panel on Climate Change (IPCC, WGL, Fourth Assessment Report, US Global Chang Research Program 2009; Larsen et.al (2008); U.S. Census Bureau (2010), Cargill, Chapin (1987).

An increase in the Earth surface temperature (the air-ground interface) leads to the melting of the perennial frozen ground near the southern boundary of continuous permafrost areas $[6,12]$.

The response of the cryolitic zone to the climate changes is related to the penetration of air temperature fluctuations into the rock formations and the subsequent changes in the temperature field of the cryolitic zone. Such penetration occurs with the time delay. With an increase in the periods and amplitude of temperature fluctuations, the penetration depth is also increased (Tables 2 and 3 ).

Table 2. Dependence of the penetration depth of the short-term temperature fluctuations on period length and amplitudes

\begin{tabular}{|l|c|c|c|c|c|c|c|c|c|c|c|c|c|c|}
\hline \multirow{2}{*}{ Indicator } & \multicolumn{10}{|c|}{ Fluctuation period, years } \\
\cline { 2 - 15 } & \multicolumn{1}{|c|}{3} & \multicolumn{1}{|c|}{5} & \multicolumn{2}{|c|}{6} & \multicolumn{2}{|c|}{10} & \multicolumn{2}{|c|}{12} & \multicolumn{2}{|c|}{25} & \multicolumn{2}{c|}{35} \\
\hline Amplitude, ${ }^{\circ} \mathrm{C}$ & 2 & 3 & 2 & 3 & 2 & 3 & 2 & 3 & 2 & 3 & 2 & 3 & 2 & 3 \\
\hline Depth & 10 & 11 & 13 & 14 & 144 & 16 & 18 & 21 & 20 & 22 & 29 & 31 & 34 & 37 \\
\hline
\end{tabular}


Table 3. Dependence of the penetration depth of medium-term and long-term temperature fluctuations on the period length and amplitudes

\begin{tabular}{|c|c|c|c|c|c|c|c|c|c|c|c|c|c|c|c|c|}
\hline \multirow{2}{*}{ Indicator } & \multicolumn{16}{|c|}{ Period duration, years } \\
\hline & \multicolumn{2}{|c|}{100} & \multicolumn{3}{|c|}{500} & \multicolumn{2}{|c|}{1000} & \multicolumn{3}{|c|}{2000} & \multicolumn{3}{|c|}{3000} & \multicolumn{3}{|c|}{5000} \\
\hline $\begin{array}{l}\text { Amplitude, } \\
{ }^{\circ} \mathrm{C}\end{array}$ & 5 & 8 & 2 & 5 & 8 & 2 & 5 & 8 & 2 & 8 & 2 & 5 & 8 & 2 & 5 & 8 \\
\hline Depth, $\mathrm{m}$ & 74 & 83 & 127 & 165 & 185 & 180 & 234 & 263 & 331 & 371 & 312 & 405 & 455 & 400 & 523 & 586 \\
\hline
\end{tabular}

As the table shows, the thermal wave for 3000-5000 years penetrated at great depth. In Western Siberia, the warming that occurred 4-8 thousand years ago with an amplitude of $2-2.5^{\circ} \mathrm{C}$ has changed the temperature profile of the criolitic zone to its entire thickness, to a depth of $400 \mathrm{~m}$ (Fig. 2).

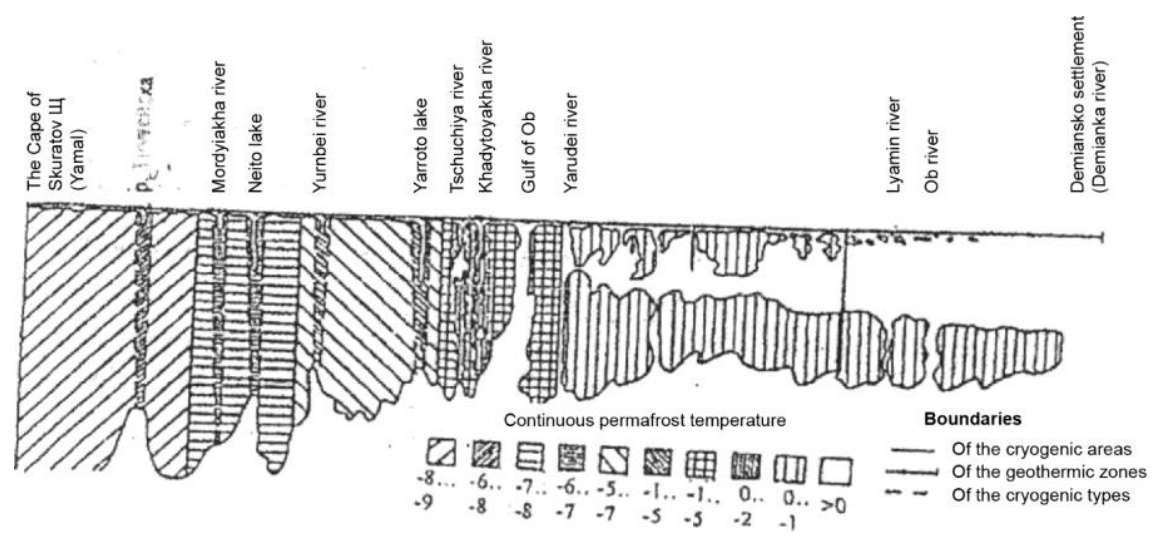

Fig. 2. Schematic section of the continuous permafrost area in Western Siberia from north to south and the rock formation temperature (Shpolyanskaya, Moscow State University, 2013, p. 40)

Due to this fact, the continuous permafrost rocks thawed to a depth of $200 \mathrm{~m}$ to the south from the Polar Circle. The smaller cycles of temperature fluctuation had the less influence when their periods and amplitude were shorter. The fall in temperature about 2-4 thousand years ago with an amplitude of about $2{ }^{\circ} \mathrm{C}$ penetrated to a depth of not more than 130-180 m. There was a new frost penetration (up to 800-100) of the thawed rocks. However, it did not reach the level of the preserved lower frozen layer that became relict.

The modern changes in the nature of continuous permafrost in the northern regions of the Urals and in Western Siberia are caused by the short-term climatic fluctuations. The short-term fluctuations in air temperature penetrate the rock formations shallowly, affecting only the first tens of meters. To the south of $67^{\circ} \mathrm{N}$, the criogenic lakes are overgrown and converted into the swamps and permafrost newly formed structures. The permafrost restoration is explained by the renewability of the forest and moss cover with its high thermal insulation properties. In the southernmost regions of the cryolitic zone, an increase in the soil surface temperature leads to the focal melting of perennial frozen soils.

\section{Changes in the state of the forest and swamp systems}

As the studies on the development of Western Siberia swamps during the Holocene age have shown $[13,14]$, the process of the forest and swamp relations has changed its direction many times, i.e. the swamp development periodically was terminated and the forest formation was intensified. These processes were determined mainly by the climatic factors, 
including the heat supply that is the changes in the soil surface temperature (air-ground interface).

Currently, there are two points of view on the intensity of modern swamp development in Western Siberia. The self-development of swamps is an extremely comprehensive process related in large part to the relief character of the terrain. The outlines of individual parts show that the swamps seem to select the most suitable areas for its advancement, or, on the contrary, temporarily stop, bypassing the higher located sections inside themselves. At the same time, even on the heavily swamped water-dividing plains, the local drainage improvement terminates the swamp development broadwise and leads to afforestation of those swamp areas where the drainage has been improved due to many natural causes, for example, the formation of an intra-swamp river system. According to F.Z. Glebov [13], a significant decrease in the annual swamp area growth over the past 200 years indicates the attenuation of the swamp development process.

Changes in the weather conditions with increasing soil surface temperature are presented by an increase in the frequency of extreme weather conditions and in an increase in its values. The statistical data indicate an annual increase in the number of natural phenomena by $6.3 \%$, and more than $70 \%$ of hazardous events occur during the warm periods of the year. More than $36 \%$ of all dangerous phenomena in the world are included in a group of four phenomena - a very strong wind, hurricane, squall, tornado; the heavy rains make up about $16 \%$ of all hazardous events; the floods and flash floods make up $9 \%$ in the total number of hazardous events.

Figures 3 and 4 show the specifications of an extreme natural phenomenon in the Middle Urals in the summer of 1990, namely the heavy precipitations and strong winds.

The existing forecasts are reliable mainly in relation to the changes in air temperature; in the inhabited atmosphere shell [9]. Other forecasted specifications (temperature conditions, precipitation regime, hydrological regimes of rivers) are shown in the specific climatic zones and seasons with low reliability [11].

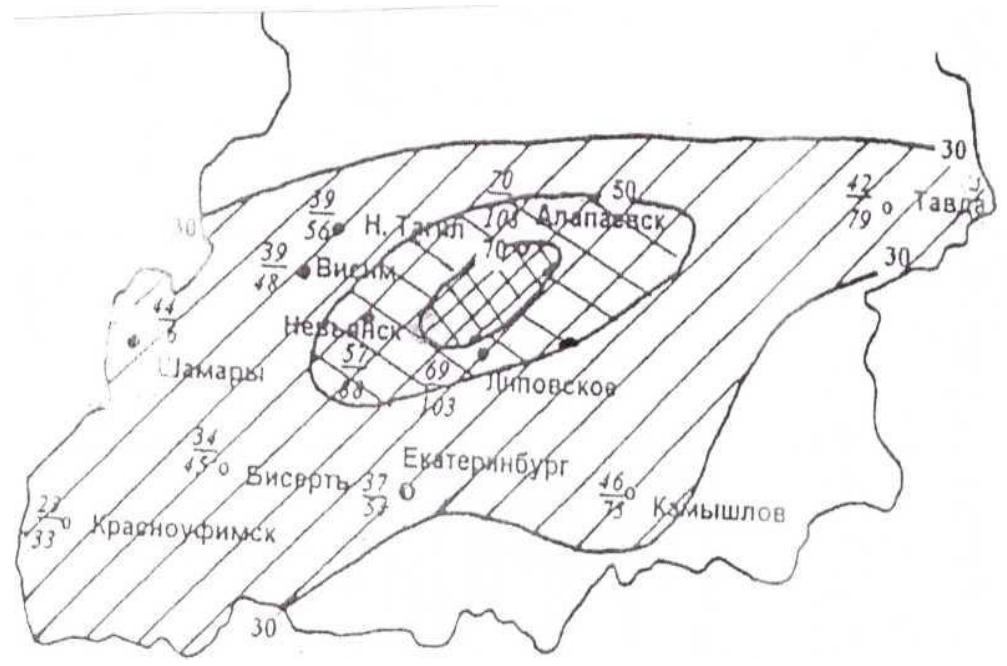

Fig. 3. Amount of precipitation (rain, snow) per day in comparison with the monthly normal range 

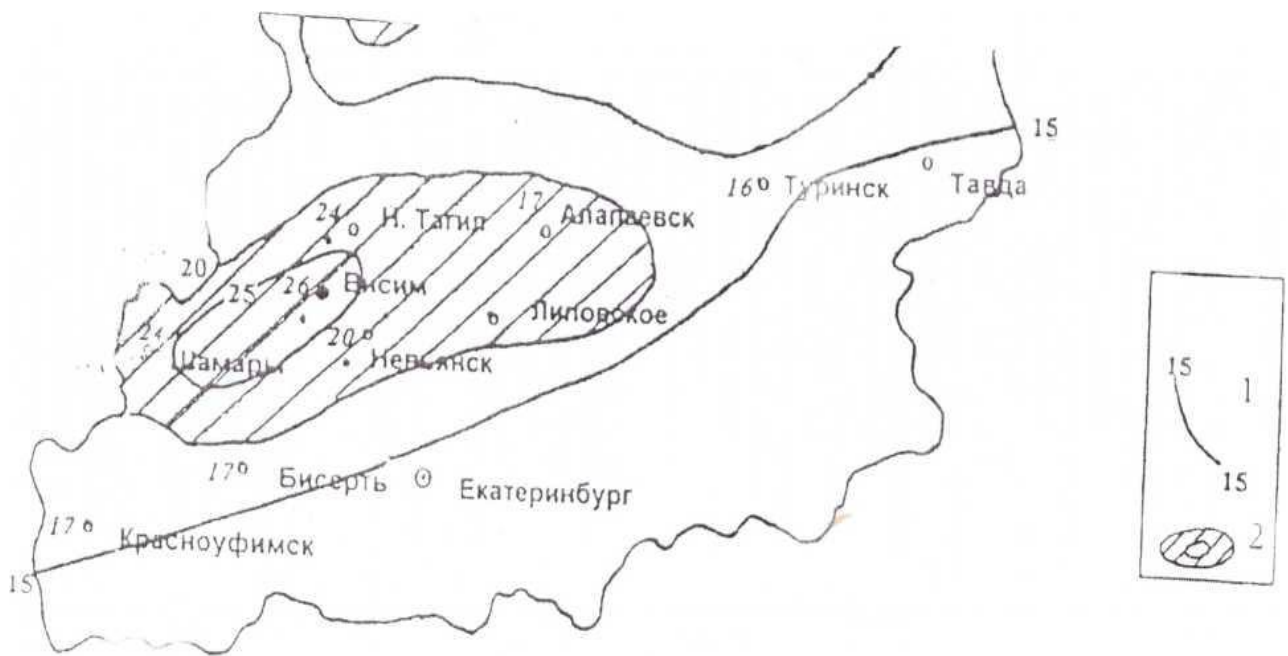

Fig. 4. Maximum wind velocity $(\mathrm{m} / \mathrm{s})$ and the area of maximum temperature effects on the forest lands: 1 - wind velocity contours; 2 - zones of maximum damage to the forest covers

\section{Economic uncertainties}

Economic uncertainties in the field of natural resource management are caused by the insufficient information on the functioning of industrial production with an increasingly difficult raw material base, the business immunity to the use of breakthrough technologies, the specifics of the business attitude towards the environmentally-friendly, energy-saving, resource efficient technologies (in the forest management, subsurface management), and the environmental nature of the consequences of the disturbed land plot restoration and use.

Environmental uncertainties in the field of natural resource management are closely intertwined with the social ones, for example, in the field of subsurface management in the civil society attitude to the income distribution and the production-based social benefit formation and consumption, in the local population attitude to the changes in the traditional form of employment and participation in the mining industry, in the attitude of the indigenous population of the North [15] to the placement of the subsurface management facilities and infrastructure in the territory of traditional natural resource management.

A.E. Natalenko et al. [16] determined the following uncertainties in the development of the mineral resource base of Russia:

- bauxites, manganese ores, uranium, fluorspar, chromite ores, titanium, zirconium and insufficient minerals the significant domestic consumption of which is mainly provided by import, and the discovery of new deposits with much better quality is unlikely;

- beryllium, lithium, rhenium, tantalum, niobium, stannum, rare earth metals are the insufficient minerals, their domestic consumption is limited and is provided by import, and the discovery of new deposits with better quality is unlikely;

- copper, lead, zinc, molybdenum, tungsten, etc. are the sufficient minerals at present, however, during the period until 2040 there may be problems related to the depletion or sharp quality deterioration of residual stocks.

The business immunity to the use of breakthrough technologies is illustrated by the small share of subsurface management organizations implementing the technological innovations; their share decreased from $6.6 \%$ (2010) to 5.5\% (2016), and the share of technological innovation costs in subsurface management in the total production cost is $1.3 \%[17, \mathrm{p} .82]$. The attitude of modern business in Russia to the new environmentallyfriendly, energy-saving, resource efficient technologies is specified by the share of the 
R\&D expenditures [18]. Figure 5 shows the comparative data on these costs in relative and absolute values.

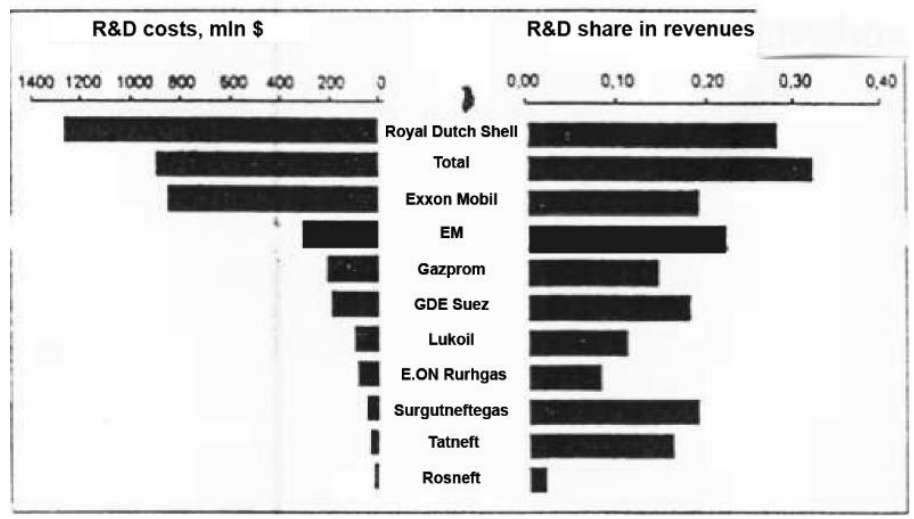

Fig. 5. R\&D expenditures by the large world oil companies (Novoselov, 2011)

The uncertainty in assessing the environmental and economic consequences of the establishment and use of the disturbed forest lands in the industrial areas is determined by the following circumstances. At present, there are no quantitative dependences of changes in properties (forest resources) and functions (environment-forming, habitat-forming, environment-protective) of the disturbed forest lands in the old industrial regions of the Urals and in the newly intensively developed territories of Western Siberia. The publications $[18,19,20]$ present the parameters of single-point pollution of the soil covering and ground cover of the disturbed lands. Information support on the contaminant movement (especially radioactive contaminants [21]) on the forest lands, depending on the terrain and specifications of the vegetation cover) indicates only the boundaries of such movement (hilltops, type of vegetation cover on the contaminated area).

At present, information support on the conversion of the single-point pollution of soil covering and ground cover of the disturbed forest lands into the diffuse forms in terms of distribution area and depth of penetration into the soil layer is insufficient, the boundaries cannot yet be specified with sufficient accuracy [22, 23].

There is no data on the nature and degree of natural and remediation restoration of the natural potential of disturbed soils, soil covering, ground cover and bush-and-wood cover in the case of various subsurface management strategies in the areas of restored forest lands.

\section{References}

1. K.N. Trubetskoy, V.N. Zakharov, E.I. Panfilov, Scientific and technical examination of subsurface management, 79 (Moscow: Institute of Comprehensive Exploitation of Mineral Resources of the Russian Academy of Sciences, 2016)

2. V.L. Chanturia, Mining Journal, 7, 29-37 (2015)

3. D.R. Kaplunov, V.A. Yukov, Mining Journal, 11, 32-36 (2015)

4. Yu.V. Lebedev, Environmentally sustainable development of territories - the patriotic view of a Soviet person, 472 (Yekaterinburg, 2017)

5. Strategy of scientific and technological development of the Russian Federation. Decree of the President of the Russian Federation № 642 dated December 1, 2016.

6. N.A. Shpolyanskaya, Continuous permafrost resistance to the global climate changes and use and protection of natural resources, $\mathbf{6}, 37-41$ (2013) 
7. V.V. Kukarskih, N.M. Devi, P.A. Moiseev, A.A. Grigoriev, M.O. Bubnov, Joumal of Mining Science, 15(4) (2018) https://doi.org,/10,1007/s 11629-017-4755-7

8. P.K. Balandin, Hell of 2012. Wreck is inevitable! 285 (Moscow: Yauza, Eksmo, 2012)

9. Z.M. Gudkovich, V.P. Karklin, V.M. Smolyanitsky, I.E. Frolov, Ecological Bulletin of Russia, 5, 34-41 (2012)

10. D.G. Zamolodchikov, Use and protection of the natural resources of Russia, 1, 36-42 (2013)

11. Z.E.B. Klyashtorin, Global environmental processes: Proceedings of the International Research Conference, 46-52 (Moscow: Academia, 2012)

12. A.V. Pavlov, Monitoring of cryolitic zone, 230 (Novosibirsk: Nauka, 2008)

13. F.Z. Glebov, Relations between the forests and swamps in the taiga zone, 184 (Novosibirsk: Nauka, Siberian branch, 1988)

14. O.L. Liss, N.A. Berezina, Swamps of the West Siberian Plain, 206 (Moscow: Publishing House of the Moscow State University)

15. V.G. Loginov, M.N. Ignatyeva, V.V. Balashenko, Economy of Region, 14(3), 896913 (2018) doi: 10.17059/2018-3-15

16. A.E. Natalenko, V.A. Pak, A.P. Stavskiy, Bulletin Use and Protection of the Natural Resources in Russia, 4, 15-20 (2015)

17. Yu.V. Lebedev, N.V. Grevtsev, R.N. Kovalev, K.V. Kokarev, T.A. Lebedeva, V.G. Krylov, Development of innovative solutions in the field of subsurface management, Ed. by Yu.V. Lebedev, 227 (Ekaterinburg: Publishing House of the Ural State Mining University, 2019)

18. A.V. Strizhenok, D.S. Korelskiy, V.S. Kuznetsov, Journal of Ecological Engineering, 20 (3), 30-35 (2019)

19. E.L. Vorobeychik, O.F. Sadykov, M.G. Farafontov, Environmental regulation of technogenic pollution of the terrestrial ecosystems, 280 (Ekaterinburg: Institute of Bioecology, 1994)

20. A.K. Makhnev, Collection of research papers (Sverdlovsk: Ural Branch of the Russian Academy of Sciences, 1990)

21. S.L. Menshchikov, V.A. Vlasenko, Forestry of the North at the turn of the centuries: proceedings of the international conference, 236-237 (Saint-Petersburg, 2000)

22. B.A. Korobitsin, Issues of Ecology and Environmental Protection, 10-11 (Yekaterinburg, 1995)

23. Biological reclamation and monitoring of disturbed lands: proceedings of the International Research Conference, 928 (Yekaterinburg: Publishing House of the Ural University, 2007) 